Zoology.-There is promise of an interesting meeting in Section D. The most important event will be the open discussion on certain problems of fertilisation, in which it is anticipated that some prominent botanists will take part. Several papers dealing with the morphology of Colenterata have been promised, including one by Mr. Duerden on corals, and one on the physiology of digestion in Alcyonarians by Miss Edith Pratt. Mr. Crossland has promised an address on his dredging experiences in Zanzibar; Prof. McIntosh will read papers on a comparison of the terrestrial and marine fauna and on variation in Ophiocoma. Among other papers that will probably prove to be of considerable interest, there is one, by Mr. M. D. Hill, on the nuclear changes in the egg of Alcyonium. The president's address will deal partly with the question of the influence of the environment in the production of variations.

Engineering.-In this section, after the president's address on Thursday, September io, a paper by $\mathrm{Mr}$. T. Clarkson on steam driven motor-cars will be dealt with. Friday, September II, will be mostly devoted to a discussion on the problem of modern street traffic, which will be opened by Colonel Crompton, R.E. If time permit, other papers will be taken on Friday. On Monday and Tuesday, September I4 and $i_{5}$, the following papers will be discussed:- Refuse destructors, by Mr. W. F. Goodrich; natural gas in Sussex, by Mr. R. Pearson; water supply of southwest Lancashire, by Mr. T. Parry; balancing of Manchester engines, by Prof. Perry; balancing of alternators, by Mr. B. Hopkinson; gas engine explosions, by Mr. H. L. Wimperis; rainfall at Seathwaite, by Dr. Mill ; and (I) cast iron used for springs; (2) alloys cast in water-cooled moulds; (3) effect of varying stresses on steel, by Captain H. R. Sankey. Several other papers will also be taken, but the final arrangements are not yet completed for these.

Anthropology.-The address of the president, Prof. J. Symington, F.R.S., will deal mainly with the significance of variations in cranial form, and will discuss the view recently revived by Prof. Schwalbe that the Neanderthal skull belongs to a distinct species of Homo, not Homo sapiens. It will also consider the relation between the external and internal form of the cranial wall. Among the papers accepted in physical anthropology are the following :--A study of the skulls from Round Barrows, in Yorkshire, by Dr. W. Wright; papers on skulls from the Malay Peninsula, by $\mathrm{Mr}$. $N$. Annandale; and on the physical character of the Andamanese, by Dr. Garson; a note on Grattan's craniometrical methods, by Prof. Symington; a paper on the papillary ridges of the hand, by Dr. E. J. Evatt; another, by Mr. D. MacRitchie, on a Mongoloid type in N.W. Europe; and important reports on Dr. C. S. Myers's work on the rank and file of the Egyptian Army, on Dr. W. H. R. Rivers's researches among the Todas, and on Mr. Duckworth's investigations among the ancient and modern populations of Crete. The committee on anthropometric methods has a valuable report, and that on the teaching of anthropology will probably report ad interim. Archæology is unusually well represented. Mr. Arthur Evans, Mr. R. C. Bosanquet, and Mr. J. L. Myres offer reports on this year's excavations in Crete; Prof. Flinders Petrie and $\mathrm{Mr}$. J. Garstang on recent work in Egypt; Mr. G. Clinch on a megalith at Coldrum, in Surrey, which illustrates certain points in Stonehenge; $\mathrm{Mr}$. Annandale on stone implements from Iceland; Dr. C. S. Myers on the ruins of Kharga in the Great Oasis; Mr. T. Ashby on Roman work at
Caerwent; and Mr. Garstang on Ribchester; while the usual report on Silchester excavation may be expected to lead to some discussion. Prof. R. S.
Conway offers an analysis of ancient Italian placenames, as illustrating the early languages. Prof. Ridgeway has a paper on the origin of jewellery, and Mr. E. Lovett on the origin of the brooch. General ethnography (with the exception of Dr. Rivers's work on the Todas), and folklore and comparative religion (apart from Mr. W. Crookes's paper on Islam in modern India) are as yet poorly represented, but this defect will probably be made good before long.

Botany.-In the botanical section the address of the president will deal with the nature and geographical distribution of floras subsequent to the Coal period; the gradual progress of vegetation from the Lower Carboniferous period through the Coal age up to the Lower Cretaceous formations will be discussed, gfeater prominence being given to the Mesozoic floras. Miss Ethel Sargant will open a discussion on the evolution of the Monocotyledons, and Prof. J. B. Farmer will give a semi-popular lecture on Epiphytes. Mr. W. Bateson will give an account of the new discoveries in heredity, Miss E. R. Saunders will describe the results of some cross-breeding experiments with plants, and $\mathrm{Mr}$. C. C. Hurst will describe some recent experiments on the hybridisation of orchids. Other papers will include an account of important recent advances in our knowledge of algæ, by Messrs. Tansley and Blackman; the sandhill and saltmarsh vegetation of Southport, by Dr. Otto V. Darbishire; on the seedlings of some grasses, by Miss Sargant and Miss Robertson; on willow canker, by Prof. T. Johnson; and on some experiments with the staminal hairs of Tradescantia, by Mr. Harold Wager. It is expected that a number of foreign botanists will be present at the meeting.

Educational Science.-The organising committee of this section has decided to continue the procedure adopted at previous meetings, namely, to confine the discussions to a few broad subjects. It is proposed to devote two days (September Io and II) to an organised discussion of school curricula, based on a series of short papers contributed by Prof. John Adams, Prof. H. E. Armstrong, F.R.S., Miss S. A. Burstall, Mr. G. F. Daniell, Mr. W. E. Fletcher, Mr. T. E. Page, Mr. J. L. Paton, and Prof. Michael E. Sadler. A joint meeting with the Geographical Section will be held to discuss the "Teaching of Geography." The discussion will be opened by Mr. H. J. Mackinder, and he will be followed by several gentlemen who have devoted special attention to this important branch of school work. In addition to these subjects, there will also be discussions on the reports of committees on :- (a) "The Conditions of Health Essential to the Carrying on of the Work of Instruction in Schools "; (b) "The Teaching of Natural Science in Elementary Schools"; $(c)$ "The Influence Exercised by Universities and Examining Bodies on Secondary School Curricula, and also of the Schools on University Requirements"; $(d)$ "The Teaching of Botany in Schools."

\section{NATIVES AND CUSTOMS OF CHUTIA} NAGPORE. ${ }^{1}$

THIS bright and picturesque book, which should be widely read, gives in its text and illustrations a vivid picture of the eastern side of Chota, called by the natives Chutia Nagpore, the motherland (Chut) of the Nagas, who were Naga-Kushikas, sons of the Naga Cobra and the tortoise. But I hope that its interesting description of the country, its inhabitants and their festivals, and its glimpses into the traditional history of the past, especially those given in chap. v. of the Santal birth legends, are only a prelude to works 1 "Chota Nagoore: a little known Province of the Empire." By F. B. Prarley Birt. Pp. xiv ${ }_{3}$ ro. (London: Smith, Elder and Co., Igo3.) 
of deeper research, in which the present author and others living in Chutia Nagpore may try to disentomb from below the present surface the ancient history of the country which was once the treasury of the Naga rulers of India, and will undoubtedly be in the future its richest manufacturing province. It contains about 5000 square miles of coal-fields, only worked on its eastern rim, inexhaustible supplies of iron ore, red and brown hæmatite, magnetite and limestone, immense wealth in other minerals, and in the remote past the gold of its gold-bearing river-sands and its diamonds filled the coffers of the Naga-Kushika kings. 'The central mountain of their realm was Parisnath, described in chap. vi., which was first the Marang Buru or Great Mother Hill of the Mundas and Santals. The Kushikas called it Mandara, the revolving mountain, and it was finally consecrated as the sacred mountain in the east of the trading Jains of the west, who gave
There the seasonal dances are held, a separate step and figure being set apart for each season, and thither in the primitive age the women of each village invited to these dances the men of one adjoining it in the same province or Parha, and there the children of each village were begotten as the offspring of the mother trees of the sacred grove. Their Spartan education, in separate establishments for each sex, by the women and men of each village to whom their mothers were sisters, still exists among the Ooraons of Chutia Nagpore, the Nagas of Assam, the islanders of Melanesia in the Indian Archipelago, and other races. They were taught to repeat the national educational and historical stories, and made thorough proficients in all their tribal duties.

We can trace in Chutia Nagpore the stages of advance from the simple primitive villages of the Mundas and Marvas to the elaborate Ooraon villages

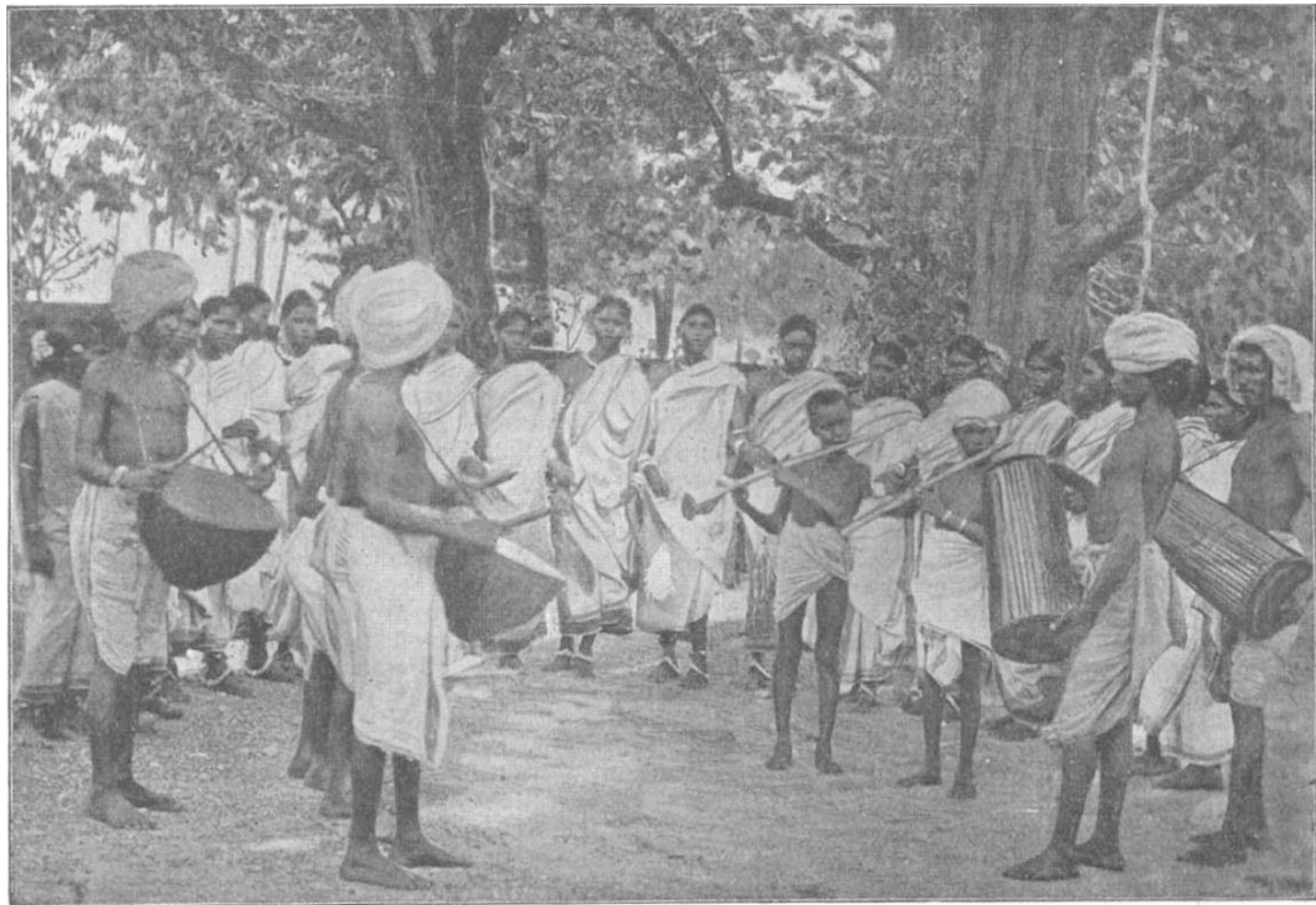

H1G. I.- Girls and Musicians at a Santal Dance.

it its present name of the Lord (nath) of Traders (Pañris).

The history of the country told in the legends, ritual and customs of its numerous tribes, takes us back through layer after layer of deposit beneath the surface of to-day to the first age of Indian village life surviving in Jushpore and Sirgoojya among the Korwas, who are nomad agriculturists living in rude huts of tree branches in forest encampments, vacated every two or three years. Their women add to the tribal food they collect in the woods and the animals killed by the men of the tribe, the produce of the crops they sow in their clearing until the soil is exhausted. Their successors were the Mundas and Marya or tree (marom) Gonds, living in permanent villages under the shade of the Sarna or village grove of old forest trees left standing in the ring of cleared rice land, the Gond tribal sacred snake. Beside the Sarna is the Akhra or dancingground, well depicted in the illustration here reproduced of Girls and Musicians at a Santal dance (p. 128). with allotments for village servants, in which the lands are divided into Manjhus or Lord's land, the Bhuinhiari land of privileged tenants eligible as Headman, Pahn or Village Priest, and Mahto or Accountant and the land of ordinary tenants, whose duty it is to till the landlord's Manjhus land. We can further study local history in the ritual customs and traditions of the laughter-loving and indomitably independent Mundas and $\mathrm{Ho} \mathrm{Kols}$, the Irish of India, of the silent and dogged Bhuyas, the musical Ooraons, forming a mixture of these two types, in the farming skill of the Kaurs and the feudal customs of the Chiroos and Kharwars, the ancestral rulers of Magadha, who attached Chutia Nagpore to their confederacy and ended the chain of aboriginal rulers, in which Mundas, Bhuyas, Gonds, Ooraons, and Kaurs were the successive links.

The three last, Ooraons, Kaurs, and Chiroo-Kharwars, were the sons of the barley as their predecessors were sons of the rice. Their national birthday is the No. I 764 , vOI. 68] 
July-August festival of the Kurum, when they dance round the national mother, the kurum almond tree (Nauclea Parvifolia), wearing barley shoots in their hair, and the festival corresponds to the Hindu Nag Punchami, the five mother snakes held in the same month. The union of the rice-eating sons of the south with the northern eaters of barley is marked by the Magh festivals of January-February (p. 102) in Chutia Nagpore, and the Magh festival of Puryag at the junction of the Jumna and Ganges, where the union with the men of the south of the Kushika Gonds, who came down the Jumna, is celebrated by the offering as sacrifices of living victims brought in by the northern people as additions to the southern ritual, in which the only sacrifices had been the first fruits of the soil offered by the primitive villagers, and the fowls slain by the Munda sun worshippers.

It was the castes who form the northern stratum of the community who began the custom of wedding brides and bridegrooms to mahua and mango trees, while almost all castes still retain the leafy marriage bower in which weddings are celebrated as a reminiscence of their ancestors, who were sons of the tree before the northern growers of oil-seeds, barley, and other crops of Asia Minor substituted individual marriages for village unions.

The last stage in primitive national history is that of the race of the trading Jains of the Bronze age, and its length is marked by the vast excavations they have made in the copper hills of Lando in Seraikela and Baragunda, under Parisnath. They formed the port of Tamluk, called Tamra-lipti or Copper-port, and have left lasting memorials of their rule in the ruins of their capital at Dalmix on the Subanrikha, their temples at Telkupi (p. $x \neq \gamma$ ), and along the ancient road to Orissa, and in the establishment of the brass-ware industry of Manbhum, which supplied the brass vessels looked on as sacred in modern Hindu domestic ritual.

J. F. HewitT.

\section{THE SEISMOLOGICAL CONGRESS IN STRASSBURG.}

$\mathrm{N}$ July of last year the British Government received an official invitation from Germany to take part in a conference the object of which was to establish ai international inquiry about earthquakes. The meetings of this conference, which took place in Strassburg-July 23 to 28 -usually commenced at 9 or Io a.m., and concluded at about 5 or 6 in the afternoon. The proceedings were reported at length in the Strassburger Korrespondenz and other papers.

At the opening ceremony the chair was occupied by His Highness Prince Hohenlohe-Langenburg, his supporters being representatives of the Imperial Government and other officials. Twenty-five States or countries were represented, but the total number of delegates and guests who were at liberty to take part in the proceedings up to the time when final votes were demanded seems to have been exactly one hundred. As sixty-two of these were Germans, it can be easily imagined that German language and German influence preponderated in debates, and although ultimate results were arrived at by the single voices of separate countries, when Great Britain and her colonies, like the German Empire, had each one vote only, it is difficult to suppose that these results are entirely free from German bias.

France was not officially represented. When we consider the powerful influence exercised by this country upon the progress of science, the impetus given to seismology by Perrey, Montessus and other workers, together with the desirability of establishing stations in French colonies, a feeling of regret arises that so important a State was unable to assist the congress. Whether this would have been the case had the same been held in some other town than Strassburg is a matter for conjecture. The chief results arrived at were as follows:-

A central association is to be formed with its headquarters in Strassburg. Each contributing country will be represented by one member on a governing committee which elects a president, a chief for the central office, and a general secretary. The chief will reside in Strassburg, but it was decided that the president and secretary should be elected from outside Germany. Although it is desirable that these officers should represent different nationalities, it is also desirable that the chief of the central office and his secretary should reside at the central office.

It was suggested that the work of the association should be as follows :-

(I) To make observations after a common plan approved by the association. Inasmuch as there now exists in connection with the British Association, in Italy, in Japan, and in other countries established systems for seismic observations, which on account of the expenditure it would involve and for other reasons could not be reduced to a common plan, and further, that as direction from a centre would destroy incentive to investigation, this proposition was abandoned.

(2) To carry out experiments on important matters.

(3) To establish and support observatories.

(4) To collect, study, and publish reports or résumés of the same.

The detailed investigations referred to in the second suggestion are not unlike headings for chapters in a treatise on seismology. This work, and that embodied in the third and fourth proposals, are for the first twelve years to be carried out at a cost of roool. per annum, and this sum is to include a salary for the general secretary. The contributions to this inadequate sum are to be apportioned amongst the cooperating States according to population, the British contribution to be $160 l$. per year. Whether the British and other Governments will take part in the scheme remains to be seen. Assuming that they do, inasmuch as roool. per year is far too small an amount to meet expenses connected with the proposed programme, it seems likely that the central office at Strassburg, in its early days at least, will become a depôt from which reports are issued and a distributing centre for earthquake registers and other materials bearing upon recent seismological research. This in itself is a work of a magnitude not generally realised, a mere catalogue of earthquakes which have been recorded during ten years in Japan, for example, making in itself a volume of I0oo pages. To reduce publications of this description, written in Chinese characters, to a form in which European investigators might wish to see them would be a labour which but few would undertake. Yet Germany offers men who are willing to face such labours, whilst her Imperial Government asks the civilised world to cooperate in carrying out the gigantic task. Now at the eleventh hour, in the name of science and because other nations are apparently unprepared or indifferent to the advantages of centralisation, it seems likely that the seismological work of all countries is to be swept into one great net.

Germany has but few observing stations and no organised system for seismological investigations of her own, yet she is willing to take beneath her ægis the organisations of the world. Whether it be in the relief of a beleaguered city or in the study of an obscure science, Germany desires to take the lead. To turn the eyes of the world towards Berlin as the centre of No. I 764 , VOL. 68] 